\title{
Author Correction: Asymmetric thinning of the cerebral cortex across the adult lifespan is accelerated in Alzheimer's disease
}

James M. Roe, Didac Vidal-Piñeiro (D), Øystein Sørensen (1D, Andreas M. Brandmaier (1), Sandra Düzel,

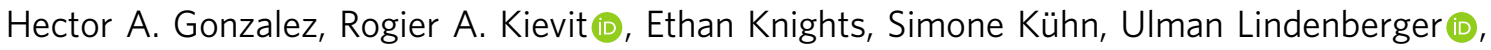
Athanasia M. Mowinckel, Lars Nyberg, Denise C. Park, Sara Pudas (D, Melissa M. Rundle, Kristine B. Walhovd (D), Anders M. Fjell, René Westerhausen (10) \& The Australian Imaging Biomarkers and Lifestyle Flagship Study of Ageing*

Correction to: Nature Communications https://doi.org/10.1038/s41467-021-21057-y, published online 1 February 2021.

In this article the affiliation details for Ulman Lindenberger were incorrectly given as 'Department of Psychiatry and Psychotherapy, University Medical Center Hamburg-Eppendorf, Hamburg, Germany' but should have been 'Center for Lifespan Psychology, Max Planck Institute for Human Development, Berlin, Germany', 'Max Planck UCL Centre for Computational Psychiatry and Ageing Research, Berlin, Germany'. The original article has been corrected.

Published online: 07 February 2022

\footnotetext{
(c) (i) Open Access This article is licensed under a Creative Commons Attribution 4.0 International License, which permits use, sharing, adaptation, distribution and reproduction in any medium or format, as long as you give appropriate credit to the original author(s) and the source, provide a link to the Creative Commons license, and indicate if changes were made. The images or other third party material in this article are included in the article's Creative Commons license, unless indicated otherwise in a credit line to the material. If material is not included in the article's Creative Commons license and your intended use is not permitted by statutory regulation or exceeds the permitted use, you will need to obtain permission directly from the copyright holder. To view a copy of this license, visit http://creativecommons.org/licenses/by/4.0/.
}

(C) The Author(s) 2022 